\title{
University Spin-offs, Entrepreneurial Environment and Start-up Policy: The Cases of Waterloo and Toronto (Ontario) and Columbus (Ohio)
}

\author{
Harald Bathelt \& Ben Spigel
}

\begin{abstract}
Version Post-print/accepted manuscript
Citation Bathelt, H., \& Spigel, B. (2011). University spin-offs, entrepreneurial (published version) environment and start-up policy: The cases of Waterloo and Toronto (Ontario) and Columbus (Ohio). International Journal of Knowledge-Based Development, 2(2), 202-219.
\end{abstract}

Copyright / License

Publisher's Statement The version of record [Bathelt, H., \& Spigel, B. (2011). University spinoffs, entrepreneurial environment and start-up policy: The cases of Waterloo and Toronto (Ontario) and Columbus (Ohio). International Journal of Knowledge-Based Development, 2(2), 202-219.] is available online at: http://www.inderscienceonline.com/doi/10.1504/IJKBD.2011.041248

How to cite TSpace items

Always cite the published version, so the author(s) will receive recognition through services that track citation counts, e.g. Scopus. If you need to cite the page number of the TSpace version (original manuscript or accepted manuscript) because you cannot access the published version, then cite the TSpace version in addition to the published version using the permanent URI (handle) found on the record page. 
March 72011

ca. 8,000 words

\title{
University Spin-offs, Entrepreneurial Environment and Start-up Policy: The Cases of Waterloo and Toronto (Ontario) and Columbus (Ohio)
}

\author{
Harald Bathelt \\ University of Toronto, Department of Political Science and Department of Geography \& \\ Program in Planning, Sidney Smith Hall, 100 St. George Street, Toronto ON M5S 3G3, Canada, \\ E-mail: harald.bathelt@utoronto.ca, URL: http://www.harald-bathelt.com \\ and \\ Ben Spigel \\ University of Toronto, Department of Geography \& Program in Planning, \\ Sidney Smith Hall, 100 St. George Street, Toronto ON M5S 3G3, Canada, \\ E-mail: ben.spigel@utoronto.ca, URL: http://www.benspigel.com
}

Re-submitted to

International Journal of Knowledge-Based Development

Special issue on "University Cities: Including Universities and Research Institutes into Strategies for Urban Growth"

Guest editor: Peter Franz (E-mail: peter.franz@iwh-halle.de) 


\section{University Spin-offs, Entrepreneurial Environment and Start-up Policy: The Cases of Waterloo and Toronto (Ontario) and Columbus} (Ohio)

\footnotetext{
Abstract (ca. 150 words). Universities can be central to a region's economic growth and development, especially if they support start-up, spin-off and modernization processes related to the regional core sectors. While many governments and associations have developed programs to encourage the establishment of university spin-offs, the policies they craft are hampered by two major problems. The first is a narrow understanding of spin-offs that focuses on firms directly based on university research. This approach misses firms that use university-related knowledge and resources, unsponsored through the university. Second, spin-off promotion policies often ignore the role of a larger regional entrepreneurial culture and supporting institutions. This paper argues that a broader view of spin-offs is required; a view that accounts for a larger array of ventures and that looks beyond the firm or university to the broader set of regional structures and relations. The empirical evidence presented draws from start-up and spin-off experiences at universities in the United States and Canada.
}

Keywords. University spin-offs, academic entrepreneurship, entrepreneurial environment, Canada, United States

JEL Classifications. L26, M13, R11, R58 


\section{Introduction}

It is now well accepted that universities can significantly contribute to regional economic growth and development by supporting start-up, spin-off and modernization processes related to local core industries. A supportive spin-off environment helps promote technology-transfer activity within the local community. According to the 'seedbed' model, new firms tend to start close to the places where their founders live, study, work or conduct research (e.g. Hayter, 1997). This is because the founders know the regional support infrastructure, suppliers and users and, in turn, are known to their environment (e.g. to regional banks). It is in this environment where initial contacts with customers are made, where new prototypes are created in a university laboratory, and where relationships with financiers first develop. The local environment thus sets the stage for the initial development of a start-up idea (Julian, 2007).

While many governments and associations have developed programs to encourage the development of university spin-offs, these policies are hampered by two major problems: The first is a narrow view of spin-offs that is focused on firms directly based on university research. This approach ignores firms that use university-produced knowledge and resources more informally; for example, start-ups created by university graduates which are unsponsored - that is unrelated to any specific research program. Empirical evidence indicates that the number of spin-offs that are directly related to university research is limited (Bathelt et al., 2011). Secondly, spin-off policies often ignore the role of a larger regional entrepreneurial environment and institutional setting, hampering potential growth once firms leave the university. This creates a situation where the few spin-offs that are created sponsored by a university lack the local connections with investors, suppliers and customers necessary for survival and growth. 
Both problems point toward the need to develop broader support policies to encourage university-related start-ups and help integrate young firms in their regional environment. As powerfully stated by Hannan and Freeman (1984), young firms need to achieve market legitimacy to be able to survive. Since university spin-offs originate in a non-commercial environment, they may encounter obstacles in acquiring the skills and competencies necessary to survive in the market (Vohora et al., 2004; Pries and Guild, 2007). By widening the focus of spin-off policies to include unsponsored start-ups by university graduates that are not based on university intellectual property (IP) and that are not sponsored by the university, the target population grows to include more firms that are a better fit for market competition. Further, by addressing the broader regional entrepreneurial environment, policies may actively aid young firms in embedding in the local economic environment. This strengthens firms' ability to survive by supporting the establishment of social/economic relationships within and across specific regional value-chain contexts.

As such, this paper's agenda is twofold. It first argues that it is vital to address the wider population of university-related start-up firms, instead of just research-based spin-offs. The second argument is the need for broader start-up policies that integrate the entire entrepreneurial environment. In what follows, the next section discusses the conceptual framework connecting spin-off processes, the entrepreneurial environment and start-up policies. The empirical part then presents the experiences of university spin-off cultures and environments around the University of Waterloo (UW) and the University of Toronto (U of T), Ontario and The Ohio State University (OSU), Columbus, Ohio. The final section summarizes the main results of this research and draws brief policy conclusions. 


\section{Spin-off/Start-up Processes and the Entrepreneurial Environment}

Universities are hubs of scientific knowledge that convey innovations and discoveries to local firms and industries (Youtie and Shapira, 2008). They can catalyze the development of high-technology clusters and aid regional economic development (Wolfe, 2005; Benneworth and Hospers, 2007). Despite the large investments by governments and firms in university research, the transfer of knowledge from laboratories to the marketplace through patents, licenses, consulting agreements, or spin-off firms has proven difficult. The linear model of innovation, where discoveries by university researchers doing basic science are transferred to the private sector that then transforms the discoveries into new products (Malecki, 1991), has proven largely ineffective (Lundvall, 1992). The transition of university-owned innovations and intellectual property into marketable products is fraught with difficulty, even when private firms invest substantial resources in licensing patents (Shane, 2004). With the failure of the linear model, attention has shifted to the importance of interactive learning processes between, for instance, university scientists and corporate technicians or by university graduates transferring the often tacit knowledge they acquire in the classroom to their employers (Nonaka and Takeuchi, 1995).

One of the major challenges of technology transfer is the professors' and other university researchers' reluctance to communicate their discoveries with their university's technology transfer office (Jensen et al., 2003). Professional advancement at most universities is based on academic publication, not on the successful commercialization of discoveries. Researchers have little incentive to spend a considerable amount of time on patenting an innovation or forming a spin-off firm if these activates are not counted towards promotion and tenure (Bercovitz and Feldman, 2008). Without these researchers' cooperation, of course, technology transfer offices cannot effectively patent and commercialize university-based innovations. 
The Bayh-Dole Act in the United States and the Canadian Science and Technology Strategy promote the patenting and commercialization of federally funded university research. The majority of universities maintain ownership of such intellectual property, keeping most of the revenues generated from patent licenses. A smaller number of universities give the inventors complete ownership of their inventions as an incentive to commercialize these on their own. This later method has been credited for generating higher rates of spin-offs because the inventor has a financial stake in the successful commercialization of technologies (Bramwell and Wolfe, 2008). But in general, few universities (examples include MIT, Stanford, Cambridge, as well as UW) have experienced any real success in creating viable spin-offs.

The continued success of these selected universities is due to institutional cultures that encourage and reward technology transfer activities like patenting and the formation of spin-off ventures (Colyvas, 2007). An institutional culture is different from an incentive system designed by administrators to promote technology transfer. A pro-technology transfer culture exists at all levels of a university, from the laboratory bench to the president's office (Murray, 2004). Such a culture cannot be imposed through administrative fiat, but emerges organically over time at a university, often set in motion by a few early success stories and strategic decisions by administrators (Saxenian, 1994). A supportive entrepreneurial culture within a university or department encourages researchers and professors to consider spin-offs a normal part of their academic career path (D'Este and Patel, 2007). Although such an entrepreneurial culture is created in the university's laboratories and classrooms, it is eventually reflected in university policies like tenure and promotion systems that take into consideration the number of patents and spin-offs a researcher creates (Bercovitz and Feldman, 2008). ${ }^{1}$

${ }^{1}$ For instance, the tenure policy at MIT's Department of Electrical Engineering counts a patent with the same weight as a publication in a high quality journal (Agrawal and Henderson, 2002). 
From a policy perspective two aspects related to regional technology transfer through universities deserve further attention: (1) the types of firms targeted by university spin-off policies and (2) the attention these policies pay to the local entrepreneurial environment. It is this wider environment that enables firms to become embedded in the regional economy and have a broader regional impact. These aspects that are discussed next are decisive to establish market legitimacy and create wider regional networks that support long-term success.

\subsection{University Spin-offs and Start-ups}

In conventional approaches, university spin-offs are understood as firms that are created by researchers to commercialize their innovations (Shane, 2004). Because universities often retain equity in spin-offs, they can generate more revenue through spin-offs than through simply licensing a patent to a firm. Since the founders maintain a relationship with the university, the firm and its employees are more likely to stay in the region. Several studies have examined what attributes of both the university and the individual professors are associated with higher rates of spin-off formation. Factors, such as the amount of external funding the entrepreneur has received (Landry et al., 2006), immigration status and gender (Hsu et al., 2007), or the university's intellectual property policy (DiGregorio and Shane, 2003), influence the rate of academic entrepreneurship and spin-off creation. There is, however, a sizable research gap about which regional economic factors, beyond the presence of venture capital, increase spin-off formation.

Few university spin-offs experience a profitable exit, in terms of an initial public offering, acquisition or merger. Most have difficulties to adapt to the rationale of market exchange and will eventually fail (Rothaermel and Thursby, 2005). Academic entrepreneurs' greatest challenge is the transition from an academic to a business culture. In the academic realm, research is prized for its contributions to the broader field of study. In an entrepreneurial setting, the research itself is secondary to the market opportunity it addresses. Numerous studies and interviews with 
entrepreneurs, venture capitalists, angel investors and technology transfer officers demonstrate the difficulty of crossing over between the academic and market worlds (Markman et al., 2005). Those without prior entrepreneurial or business experience lack the knowledge and information sources needed to identify a market opportunity, raise the necessary capital and create a successful firm strategy (Mosey and Wright, 2007). Too often, a firm focuses on a groundbreaking innovation instead of how that innovation meets an existing market need (Lockett et al., 2003). Unsponsored spin-offs are less protected from the marketplace by academic structures and, therefore, often face a less difficult transition from a university to an entrepreneurial culture.

Because of these problems, it is useful to broaden our view of university-related spin-off activities. In general, technology transfer policies should address all new firms that draw upon knowledge produced or circulated at the university, firms whose founders met at or through the university, and where business opportunities are an outcome of the university's existing areas of competence in research and teaching (Bathelt et al., 2010). In terms of university involvement (Mustar et al., 2006), this entails (1) spin-offs based on intellectual property developed at the university, (2) spin-offs which result from university-industry joint ventures, and (3) start-ups resulting from decentralized individual or collective ideas developed at the university, unrelated to the university's research programs (Table 1). By ignoring the latter type of firms, spin-off policies miss an important constituency of academic entrepreneurs. While most spin-offs will benefit from institutional support, sponsored and unsponsored spin-offs require different kinds of support. Firms led by professors commercializing patented university research have different needs than firms started by students based on ideas they had in the classroom (Pirnay et al., 2003). All in all, the focus of technology transfer policies should also include less risky marketrelated and not just research/technology-driven start-ups (Bathelt et al., 2010). 
Table 1. Typology of spin-offs and start-ups according to university sponsorship and involvement in firm formation processes

\begin{tabular}{|c|c|c|c|}
\hline \multirow{3}{*}{$\begin{array}{l}\text { University } \\
\text { sponsorship }\end{array}$} & \multicolumn{3}{|c|}{ University involvement in spin-off and start-up processes } \\
\hline & \multicolumn{2}{|c|}{ University spin-offs } & \multirow{2}{*}{$\begin{array}{l}\text { University-related start- } \\
\qquad \text { ups } \\
\text { Decentralized idea } \\
\text { development }\end{array}$} \\
\hline & University research & $\begin{array}{l}\text { University-industry joint } \\
\text { ventures }\end{array}$ & \\
\hline $\begin{array}{l}\text { Sponsored } \\
\text { spin-offs }\end{array}$ & $\begin{array}{l}\text { Intellectual property } \\
\text { (IP) development at } \\
\text { the university } \\
\text { through publicly } \\
\text { funded research } \\
\text { grants }\end{array}$ & $\begin{array}{l}\text { Formal development } \\
\text { agreement between } \\
\text { university and industry; } \\
\text { typically involves } \\
\text { preferential licensing } \\
\text { rights for IP }\end{array}$ & $\begin{array}{l}\text { Firms started by } \\
\text { graduates after they } \\
\text { finish school; might } \\
\text { develop a business idea } \\
\text { from joint classroom } \\
\text { experience }\end{array}$ \\
\hline $\begin{array}{l}\text { Unsponsored } \\
\text { spin-offs/ } \\
\text { start-ups }\end{array}$ & $\begin{array}{l}\text { Researchers develop } \\
\text { an idea within the } \\
\text { university, pay for } \\
\text { the IP and then leave } \\
\text { without support of } \\
\text { the university }\end{array}$ & $\begin{array}{l}\text { Off-site, unsolicited } \\
\text { innovation brought } \\
\text { forward by someone in } \\
\text { the research group and } \\
\text { developed into a } \\
\text { product }\end{array}$ & $\begin{array}{l}\text { Completely self- } \\
\text { developed firms; } \\
\text { founders meet } \\
\text { informally, off-site or } \\
\text { outside campus but } \\
\text { have social ties with the } \\
\text { university }\end{array}$ \\
\hline
\end{tabular}

Source: based on Bathelt et al. (2010, p.523)

Market-driven university start-ups can, of course, also suffer from some lack of management experience. Entrepreneurial training, in this case, helps overcome the lack of specific business competencies (Mosey et al., 2006). However, this is not enough. University spin-offs require a local entrepreneurial infrastructure to support them as they mature and grow. This infrastructure includes both financiers like venture capitalists and angel investors, as well as business services like patent attorneys and specialized accountants, along with local policy frameworks and institutions to incubate young firms (Kenney and Patton, 2005). Spin-offs need both time and money to convert a laboratory-based innovation into a marketable product. They 
require risk capital and advisers who have navigated the spin-off process before in order to survive this gap. This shifts the view to the wider spin-off environment in a region.

\subsection{Regional Entrepreneurial Environment and Culture}

Start-up resources, like venture capital to support early-stage R\&D-based firms, are not evenly spread throughout an economy but are rather concentrated in certain cities and regions (Sorenson and Stuart, 2001; Powell et al., 2002). Venture capital is vital for technology firms that need to finance several years of development before a marketable product is produced (Samila and Sorenson, 2010). Venture capitalists and business angels, in turn, prefer to invest locally to better supervise the firms they back (Zook, 2002; Griffith et al., 2007). More generally, start-up firms benefit from a pool of specialized local suppliers, users and service providers that they can link up with, as well as a skilled labour market.

Some of the most valuable resources in the regional environment are available through personal social networks. The researchers' and students' personal networks are critical for establishing and maintaining connections with agents outside the academic world - agents that may have access to complementary resources such as specialized user networks. By informally integrating private and business relationships, entrepreneurs can gather broad information about market conditions, access to capital and potential customers (Malecki, 1997; Arenius and de Clercq, 2005). Spin-off firms are less likely to survive if the founders' personal networks are heavily biased towards university colleagues who possess few of the resources they require (Mosey and Wright, 2007). Potential investors and clients use their own networks to evaluate both the spin-off firms and their founders. If the founders are not part of such networks that develop around daily activity spaces, investors experience difficulties in gathering information on their potential investment targets (Shane and Cable, 2002). Academics' networking patterns are affected by institutional factors. A proactive technology transfer office or local economic 
development office can set up programs like lectures or bar nights to encourage interaction between academics and financiers. This points toward the need to engage more specifically with the roles of regional/local policies that may trigger start-up processes and help actively embed new ventures in their local environment.

A supportive entrepreneurial infrastructure, rich institutional environment and potential supplier-producer-user networks on the one hand, as well as successful entrepreneurial practices and traditions (mediated to the public and potential future entrepreneurs via successful role models) on the other hand, have the potential to form a specific entrepreneurial culture (Malecki, 2009), such as the high-risk, open-architecture venture culture in Silicon Valley or the large-firm, proprietary innovation culture in Boston's Route 128 region (Saxenian, 1994). It is the combination of specific entrepreneurial structures and embedded relationships that may lead to a regional entrepreneurial culture, which, in turn, can increase firm creation and spin-off formation. Regional entrepreneurial cultures promote and legitimize the business aspirations and risk-taking activities of both entrepreneurs and investors that are necessary for the formation of growthoriented spin-offs (Aoyama, 2009).

Entrepreneurial cultures do more than just attract resources to a region. Over time, a series of successful entrepreneurs may alter the regional social structure (Malecki, 2009). Prominent successful entrepreneurs legitimize entrepreneurial risks, encouraging both new firm formation and spin-off activities. Entrepreneurial cultures legitimize risky investments in startups, not only by professional investors but also through informal sources of financing like family and friends or local business angels. University policies must take into account these regional environmental and cultural factors if they are to effectively support the transition of spin-offs to market requirements. 


\subsection{Toward an Integrated Regional Start-up/Spin-off Conception}

Frequently, research on university spin-offs focuses on sponsored spin-offs - firms based on an innovation formally declared to the technology transfer office that evaluates the intellectual property and creates a legal agreement for the inventor. Recent work, however, suggests that such sponsored spin-offs represent only a minority of all firms started by academics (Langford et al., 2006; Bathelt et al., 2010). Fini et al. (2010), for instance, show that over two thirds of spin-offs are based on intellectual property that was not disclosed to the university. Academics have several reasons for declining to disclose innovations to their university's technology transfer office. They may not want to dedicate the substantial time and energy needed to work with this office; or they may strategically choose not to disclose to ensure the university has no control over the invention (Jensen et al., 2003). As a result, many university spin-offs go undetected by universities and are unrecorded in official statistics. Many of these unrecorded, unsponsored spin-offs are started by university graduates combining what they learned in the classroom or laboratory in creative ways. They are not based on patented intellectual property and, therefore, have no need to communicate with the technology transfer office (Table 1; Fini et al., 2010). The majority of these firms appear to be consulting firms rather than R\&D-intensive firms (Martinelli et al., 2008).

Langford et al. (2006) argue that spin-off policies focus too heavily on sponsored spinoffs from university research, ignoring the large number of unsponsored spin-offs that are informally organized around university-produced intellectual property or on knowledge of a public good character (Bathelt et al., 2010). As a result of the metrics used, current university spin-off policies focus on sponsored, research-driven firm formation and neglect unsponsored start-ups from decentralized idea development. While unsponsored spin-offs are less likely to be 
based on major innovations, these firms may be the fittest new ventures and could have a significant regional impact if supported by the respective regional spin-off/start-up policies.

Research on spin-offs normally employs data collected by the Association of University Technology Managers (2010), tracking national and global trends in university spin-offs and patenting, or on the population of spin-offs provided by university technology transfer offices. Policies based on this research ignore the important role played by unsponsored spin-offs. The suggestions derived from the above conceptual debate for regional technology transfer policies are to (1) use a broader approach to identify university-related start-ups and (2) include the wider entrepreneurial environment and culture into support programs. The experiences and shortcomings that arise from different policy approaches are illustrated in three case studies in the next section.

\section{Case Studies}

This section discusses how policies at three universities - the University of Waterloo (UW), the University of Toronto (U of T) and The Ohio State University (OSU) - and their regional entrepreneurial environments have affected the production of spin-off firms. Table 2 shows data on the universities' history of technology transfers from 1996 to $2008 .{ }^{2}$ On the surface, the data seem to show that UW has had the least success of the three universities. It has the fewest patents issued, as well as the smallest number of spin-offs and disclosures of new inventions by faculty. This may be due to the fact that UW is substantially smaller than the other two universities. It receives about a quarter of the research funds compared to $\mathrm{U}$ of $\mathrm{T}$; yet, despite the lower funding levels, it generates more spin-offs per research dollar than $\mathrm{U}$ of $\mathrm{T}$ or

\footnotetext{
${ }^{2}$ However, as cautioned in the preceding section, the data in Table 2 does not account for unsponsored spin-offs.
} 
OSU. On average, UW generates one spin-off firm for every 56.6 million US-Dollars of total research funding. $\mathrm{U}$ of $\mathrm{T}$ produces one spin-off for every 82.4 million US-Dollars and OSU one for every 128.1 million (Association of University Technology Managers, 2010). A significant factor in this is UW's intellectual property policy, which allows researchers to maintain ownership of their discoveries. As argued below, the entrepreneurial culture of the university has provided the base for substantial unsponsored spin-off formation by researchers.

Table 2. Technology transfer statistics for the University of Waterloo (UW), the University of Toronto (U of T) and The Ohio State University (OSU)

\begin{tabular}{|c|c|c|c|c|c|c|c|c|c|c|c|c|}
\hline \multirow[t]{2}{*}{ Year } & \multicolumn{3}{|c|}{$\begin{array}{c}\text { Research } \\
\text { expenditures } \\
\text { (million US Dollars) }\end{array}$} & \multicolumn{3}{|c|}{$\begin{array}{l}\text { US patents issued } \\
\left.\text { (number) }^{*}\right)\end{array}$} & \multicolumn{3}{|c|}{$\begin{array}{l}\text { Spin-offs created } \\
\text { (number) }\end{array}$} & \multicolumn{3}{|c|}{$\begin{array}{c}\text { Innovations } \\
\text { disclosed (number) }\end{array}$} \\
\hline & UW & $\begin{array}{l}\mathrm{U} \text { of } \\
\mathrm{T}\end{array}$ & OSU & UW & $\begin{array}{c}\mathrm{U} \text { of } \\
\mathrm{T}\end{array}$ & OSU & UW & $\begin{array}{l}\text { U of } \\
\mathrm{T}\end{array}$ & OSU & UW & $\begin{array}{c}\text { U of } \\
\mathrm{T}\end{array}$ & OSU \\
\hline 1996 & 33.7 & 283.8 & 207.7 & 8 & 5 & 21 & 0 & 6 & 0 & NA & 105 & 63 \\
\hline 1997 & 50.1 & 284.7 & 205.4 & 9 & 7 & 27 & 1 & 11 & 2 & 15 & 112 & 71 \\
\hline 1998 & 55.5 & 301.1 & 209.7 & 6 & 7 & 24 & 1 & 11 & 0 & 5 & 112 & 75 \\
\hline 1999 & 56.4 & 310.4 & 258.0 & 6 & 6 & 18 & 0 & 5 & 0 & 8 & 90 & 100 \\
\hline 2000 & 72.3 & 416.7 & 289.5 & 5 & 13 & 28 & 0 & 9 & 2 & 8 & 127 & 106 \\
\hline 2001 & 77.9 & 483.0 & 348.5 & 4 & 13 & 22 & 1 & 6 & 8 & 5 & 132 & 109 \\
\hline 2002 & 110.5 & 257.2 & 361.1 & 2 & 11 & 20 & 0 & 8 & 8 & 10 & 130 & 115 \\
\hline 2003 & 94.5 & 307.2 & 416.0 & 6 & 3 & 21 & 13 & 7 & 4 & 9 & 138 & 130 \\
\hline 2004 & 97.8 & 290.1 & 447.0 & 0 & 4 & 26 & 7 & 5 & 6 & 11 & 164 & 161 \\
\hline 2005 & 104.7 & 384.9 & 511.5 & 0 & 8 & 38 & 2 & 3 & 2 & 8 & 224 & 166 \\
\hline 2006 & 119.1 & 409.1 & 652.3 & 1 & 15 & 27 & 2 & 1 & 5 & 18 & 165 & 145 \\
\hline 2007 & 124.4 & 401.4 & 720.2 & 0 & 16 & 25 & 2 & 8 & 3 & 11 & 139 & 165 \\
\hline 2008 & 130.4 & 421.2 & 702.6 & 1 & 15 & 15 & 1 & 7 & 5 & 26 & 159 & 142 \\
\hline
\end{tabular}

Note: ${ }^{*}$ Since US patents are more valuable, most Canadian universities pursue them along with Canadian patents; $\mathrm{NA}=$ not available.

Source: Association of University Technology Managers (2010) 
To study the entrepreneurial environments of the three universities, we combine findings from previous studies (Spigel, 2008; Bathelt et al., 2010), which used interviews with key informants, entrepreneurs and financiers. ${ }^{3}$ All three universities are important publicly-funded universities but differ in their academic focus, technology transfer policy and size. One of the challenges in studying unsponsored spin-offs is that no standard measure of spin-offs exists and that information about such processes is usually not available. Only in Waterloo, which commissioned a specific study (PricewaterhouseCoopers, 2001) looking deeper into the phenomenon, do we have information that allows us to identify unsponsored spin-offs.

\subsection{University of Waterloo}

The Waterloo region early on laid the foundation for a supportive economic and social spin-off environment. This was unexpected since the region traditionally had a strong presence of a conventional manufacturing sector around the metal-fabricating/processing, electrical equipment and automobile supplier industries (Bathelt et al., 2011). Specifically surrounding the activities of UW, numerous IT-related firms, such as Dalsa, Open Text, the now famous Research in Motion (RIM) and Sybase, were successfully launched, altogether establishing a growing technology base (Bathelt and Hecht, 1990; Colapinto, 2007; Bramwell et al., 2008).

The spin-off environment is directly related to UW's foundation in 1959 as an engineering-focused institution. Industrial leaders played an important role in the design of the university's mission, helping shape the university's co-operative education program and its openness toward private sector collaboration and funding (Bathelt and Hecht, 1990; Bramwell and Wolfe, 2008). Specifically, this industry-orientation led to the development of UW's intellectual property policy that allows faculty to retain the rights to their innovations. Compared

${ }^{3}$ While these studies originally had different goals, the questions asked and information collected allows us to compare the university spin-off processes and regional support policies, as well as related shortcomings. 
to other Canadian universities, UW not only has a more pronounced focus on establishing university-industry linkages, but also developed a stronger focus on applied research, focusing on technologies of potential economic value. As a consequence, UW became Canada's largest research university in the late 1960s with 533 researchers, representing about a quarter of all researchers at Canadian universities (Niosi 2000). ${ }^{4}$

The successful generation of university spin-offs was supported by a regional entrepreneurial infrastructure that provided "institutional thickness" (Amin and Thrift, 1995). It began with the establishment of Canada's Technology Triangle Inc., an organization formed to advertise the technological strengths of the wider region and reduce inter-municipal competition among the surrounding cities (http://www.techtriangle.com/index.php, date accessed February 15, 2011). This initiative cooperates closely with Communitech, an industry-led business organization that was started in 1997 with the goal of strengthening the region's technology base. Communitech partners through various initiatives with public entities from all levels of government, business associations, educational institutions and technology organizations (http://www.communitech.ca, date accessed February 23, 2011). Supported by these organizations, UW established a research park and incubator centre for university-related startups. The Accelerator Centre targets technology-related start-up and spin-off ventures providing them with subsidized space, office infrastructure and mentorship from established technology entrepreneurs to accelerate the growth of new technology firms

(http://www.acceleratorcentre.com/, date accessed February 19, 2011). The university's policies explicitly involve these organizations in encouraging entrepreneurship among students and faculty, and the Centre for Business, Entrepreneurship and Culture, which operates out of the university's engineering school, is designed to foster connections between (1) sponsored and

\footnotetext{
${ }^{4}$ In comparison, $\mathrm{U}$ of $\mathrm{T}$ had only 256 researchers at this time (Niosi, 2000).
} 
unsponsored spin-offs and student entrepreneurs and (2) the local entrepreneurial environment, through programs like entrepreneurs-in-residence (http://www.cbet.uwaterloo.ca, date accessed February 24, 2011). These programs represent a deliberate and focused strategy of continual engagement with the local entrepreneurial and technology community.

Altogether, this institutional environment has encouraged substantial spin-off activities from university research and helped establish a distinct local entrepreneurial culture. This did not just trigger the formation of 47 spin-off firms directly from university research by 2007 ; it also supported broader university-related firm formation processes not linked to UW research. Based on PricewaterhouseCoopers (2001), a total of 288 firms associated their existence in the region with the presence of local universities (mostly UW). About $40 \%$ of these firms were in the IT field and $30 \%$ in engineering (Bathelt et al., 2011).

As such, the impact of UW's innovation policies and the regional entrepreneurial environment reached beyond the production of research-based technology spin-offs. Almost half of the IT-related ventures investigated (Bathelt et al., 2010) can be classified as unsponsored, decentralized start-ups, which did not derive their technological competence from specialized university research or university-industry joint ventures. The remaining firms received at least some level of inputs or resources from UW that were, to a varying degree, important in the process of establishing the business. Over time, however, firms that were originally based on university-generated research tended to have less input or stimulus from the university. Nonetheless, even unsponsored decentralized ventures considered the university a vital element in their development, despite not having received support at the time the firm was established. As the successful case of Research in Motion demonstrates, the strong market orientation of unsponsored start-ups can lead to long-term competitive success, even when this is based on more generic knowledge flows from the university (Bathelt et al., 2010). 
In the case of UW, the university's initial advantage in fostering spin-off and start-up processes has decreased over time, as the number of new ventures is in decline (Bramwell and Wolfe, 2008). This is related to the relatively small, broadly diversified regional economy, the lack of strong inter-sectoral linkages and regional producer-user networks, as well as the need for a broader start-up policy to engage with the entire spectrum of new ventures and their entrepreneurial environment.

\subsection{University of Toronto}

$\mathrm{U}$ of $\mathrm{T}$ is one of North America's premier research universities. The Toronto region has long been the industrial, commercial and financial heart of the Canadian economy and more recently has sought to create knowledge-intensive clusters in the city, especially in biotechnology and the pharmaceutical sector. At the heart of this plan have been massive government and private sector investments in what is known as the "Toronto Discovery District" ${ }^{5}$, several square blocks encompassing $U$ of $T$ and its affiliated research hospitals that are specifically targeted for biotechnological and medical R\&D and associated start-up firms. In 2008 , the most recent year with data, this area contained 56 public research organizations, and 44 private biotechnology firms, including many start-up firms (City of Toronto - Economic Development, Culture \& Tourism, 2008).

The Discovery District is anchored through MaRS, a charitable trust organized to support high-technology start-ups and spin-offs in the software, biotechnology and pharmaceutical markets. As an incubator facility, MaRS provides entrepreneurs with subsidized office and laboratory space along with advice on subjects ranging from writing business plans to strategic marketing. These services extend to helping affiliated start-ups find both funding and specialized

${ }^{5}$ This area is also referred to as the "MaRS Discovery District"; "MaRS" was originally used as an abbreviation for "Medical and Research Sciences", but now stands for itself. 
start-up executives (http://www.marsdd.com/, date accessed February 22, 2011). One of MaRS' largest programs is its "Entrepreneurship 101" class. Originally designed specifically for U of T students, the lecture series focuses on skills like intellectual property law, opportunity identification and raising capital that are critical for high-technology start-ups. Though the program was originally oriented towards graduate students, organizers say that it is largely dominated by business students and entrepreneurs not affiliated with $\mathrm{U}$ of $\mathrm{T}$ (Interview with MaRS official, 2008). This program represents an important, if partial, attempt to support unsponsored spin-offs.

$\mathrm{U}$ of $\mathrm{T}$ is one of MaRS' primary financiers and its investments in the organization can be seen as an attempt to establish an entrepreneurial culture. While $\mathrm{U}$ of $\mathrm{T}$ has created a considerable number of sponsored spin-offs, the university lacks a specific entrepreneurial culture comparable to that of UW or other well-known entrepreneurial universities. ${ }^{6}$ Despite the large absolute number of sponsored spin-offs (Table 2), the university has yet to produce a spinoff that can serve as a role model to encourage further entrepreneurship among other faculty and students. U of T's intellectual property policies allow for the inventor to retain some of the earnings, but not to achieve full ownership and rights to their discoveries, further discouraging academic entrepreneurship. Few, if any, departments in the university consider spin-offs or patenting activity towards tenure or promotion. These cultural and institutional factors serve to limit entrepreneurship within the university.

While U of T's entrepreneurial culture is underdeveloped, Toronto itself is Canada's largest hub of high-technology entrepreneurship. There are dozens of venture capital firms located in the city and the size of the economy means that there is a large population of successful business people willing to serve as angel investors and mentors to a new generation of

\footnotetext{
${ }^{6}$ This is also associated with the fact that its research focus within the Canadian innovation system started relatively late (Niosi, 2000).
} 
entrepreneurs. This local entrepreneurial support helps to foster unsponsored spin-offs by students. For example, a software firm based on a U of T student's MA thesis was recently acquired by Google. The company, Bump Top, received early-stage financing and advice from local angel investors (http://www.cbc.ca/technology/story/2010/05/03/tech-google-bumptopcomputer.html, date accessed October 7, 2010), and the acquisition was aided by Google's local satellite office. This example shows the ability of unsponsored spin-offs to quickly attract substantial interest and support from a local entrepreneurial environment.

Toronto's economy can be viewed as relatively hospitable to academic entrepreneurship, even if U of T's culture is not particularly conducive to such ventures. The urban environment is beneficial to unsponsored spin-offs by students transitioning their own ideas from the laboratory or classroom to the marketplace. Educational programs like the "Entrepreneurship 101" class series and the presence of risk capital, entrepreneurial mentors and role models creates a favourable environment for high-technology start-ups. At the same time, the entrepreneurial environment in Toronto is quite diversified, and many specific activities such as start-up and spin-off processes may go unnoticed in this diversified urban buzz. In other words, $U$ of $T$ has less influence on Toronto's entrepreneurial environment than UW has in Waterloo. Both MaRS and $\mathrm{U}$ of $\mathrm{T}$ are less connected to Toronto's entrepreneurial institutions than their counterparts in Waterloo. These weak connections make it difficult for entrepreneurial students and faculty to become embedded in the local environment before starting a firm.

\subsection{The Ohio State University}

OSU is Ohio's flagship research and liberal-arts university. The applied sciences accounted for $78 \%$ of the 716 million US-dollars spent on research in 2009 (The Ohio State University Office of Research, 2009). This reflects both the university administration's and state policy makers' desire that OSU serves as an engine for knowledge-based growth in the state. 
However, OSU's contribution to the growth of high-technology industries has been limited in the past (Cetindamar and Lagge-Hellman, 2003). The university has had few successful spin-offs despite the sizable amount of research conducted there. This is partially due to the preference of the university's technology transfer office to license patents to existing firms, rather than encourage spin-offs. This strategy is an unforeseen result of the Bayh-Dole Act, which does not simply allow universities to patent research, but mandates it. For many universities, technology transfer offices are a compliance cost instead of a profit centre. Patents licensed to existing firms secure a steady, if small, revenue stream. In contrast, spin-offs can potentially generate substantial revenues for the university, but if they fail they produce nothing. Since patenting an innovation can be very costly, OSU's technology transfer office prefers to focus on the more reliable source of income.

OSU faces many challenges in spin-off creation because the Columbus region lacks an entrepreneurial culture and infrastructure (Spigel, 2008). The major private sector R\&Dintensive firm in the area, the Battelle Memorial Institute, is not a local university-related start-up like Waterloo's RIM or a satellite office of a major multinational firm, but a quasi-government research laboratory. It is a contract research firm that employs more than 7,500 researchers and support staff and has global revenues in excess of 5 billion US-Dollars. A major portion of Battelle's business consists of providing research services to the US military and managing federal laboratories. Battelle has few interactions with local firms because of unique security requirements. Consequently, Battelle generally does not support spin-offs from OSU, but instead actively invests in ventures emerging from its own internal research. Of the 19 firms that have spun out from Battelle, however, none is located in the Columbus region (http://www.battelleventures.com, date accessed October 5, 2010). 
The lack of spin-off activity from OSU and Battelle is related to the lack of early-stage venture capital based in the area. Over $90 \%$ of the 172 million US-Dollars in venture investments in the region ( $34 \%$ of the total venture activity in the state) came from outside the region in 2008 (Centre for Entrepreneurship, 2009). This shows that outside investors recognize the quality of local firms and technologies, but it also signals the lack of local venture and angel investors. Local investors are more knowledgeable about the potential of near-by firms and act as pipelines connecting spin-off and start-up firms with investors, partners and customers both within and outside the region. The lack of angel and venture capitalists in Columbus is problematic because local investors can provide important connections with local suppliers and clients. Without access to investors' personal networks, spin-offs in Columbus face a difficult transition from a R\&D-based start-up to a stable product-based firm.

The city has some supportive entrepreneurial institutions, including TechColumbus, a non-profit economic development agency that promotes entrepreneurship through both networking and educational events. TechColumbus also operates an incubator centre that is used by several OSU spin-offs. Of the 33 firms currently incubated, at least one third are based on university-produced technology (http://www.techcolumbus.org/clients-and-graduates, date accessed February 24, 2011). Even more have been created by OSU graduates and incorporate some element of university-produced knowledge. However, no data exist on the overall number of unsponsored spin-offs by OSU faculty and students.

OSU's relatively low levels of sponsored spin-off creation are not just a result of a lack of external financing and support. OSU, like U of T, generally lacks an entrepreneurial culture. The majority of faculty members have few reasons to establish and grow a spin-off firm. Few departments consider patenting and spin-off activity in their tenure and promotion review, nor are there any official ways to pause the tenure or promotion process to form a spin-off. The lack 
of an entrepreneurial culture, however, goes beyond administrative rules. Without prominent local success stories of academic entrepreneurs who excel in both their academic and commercial careers, laboratory directors have little incentive to allow their employees to consider patenting or entrepreneurship. The absence of an entrepreneurial culture extends to the Columbus region, whose economy is dominated by the university, the state government and a few large insurance companies. The region lacks the entrepreneurial support structure of larger urban centres and has few entrepreneurial role models who could inspire and motivate academic entrepreneurs.

\section{Conclusion}

This paper discusses the prospects of successful regional technology transfer through universities. While universities affect their regional economy in many ways, we focus here on the role of university-related spin-off processes that can potentially have a strong regional impact. Although our paper has a clear policy focus, our starting point is to conceptualize university spin-offs and the environment that supports this process. Empirical studies show that sponsored spin-offs are few in number. While conventional spin-off policies seem to focus on such ventures, we argue that another group of unsponsored firms, which develop based on decentralized idea development, have a stronger market focus and may more easily make connections with the regional economy. But without supportive policies, these firms may also struggle in their early years. As such, it appears necessary to use a broader definition that includes both sponsored research spin-offs and unsponsored university-related start-ups that are market-driven. By only focusing on sponsored spin-offs from university-owned intellectual property, technology transfer offices and policy makers ignore a large population of nascent academic entrepreneurs. 
From a policy perspective, it is further necessary to emphasize the need for a broader policy approach that goes beyond the immediate start-up constellation. Policies need to initiate and support the broader entrepreneurial environment that includes access to finance, knowledge services, supplier-producer-user networks and the institutional conditions. They should also support the development of a specific entrepreneurial culture that builds on primary start-up traditions, early success stories and dominant practices of financing and start-up routines. Spinoffs depend on a supportive set of entrepreneurial institutions and cultures both within the university and the local community. Universities must not be islands of innovation but rather aim to foster linkages between researchers and the regional entrepreneurial environment.

Our three case studies draw a differentiated picture regarding the conditions for university-related start-up and spin-off processes. Our first case, UW - the smallest of the three universities, has been very successful in producing sponsored and unsponsored start-up and spinoff firms around a well-developed entrepreneurial environment, a rich array of supportive institutions and a specific entrepreneurial culture. The second case, $\mathrm{U}$ of $\mathrm{T}$, although located in the centre of the Toronto region that has made huge investments to establish a knowledge infrastructure in biotechnological and pharmaceutical fields, has failed to develop successful spin-offs that could act as role models or help foster an entrepreneurial culture. Universityrelated start-ups can easily go unnoticed in the city's diversified urban buzz environment and need stronger catalyst functions to become identifiable as such. OSU, our third case, is characterized by few university-related start-ups and spin-offs. This is related to a lack of entrepreneurial traditions and few incentives for such processes. The local entrepreneurial environment is dominated by government-related research, and thus lacks the dynamics of competition and variety that are characteristic of private markets. 
Together, the three case studies indicate that start-up policies need to be carefully designed to increase the prospects for success. This involves a comprehensive understanding of university-related spin-off processes involving sponsored and unsponsored ventures. It also involves the formulation of a broader policy approach that addresses more dimensions of the entrepreneurial environment and supports the establishment of a place-specific entrepreneurial culture.

\section{Acknowledgements}

We wish to thank Peter Franz for his support and appreciate the excellent comments that helped insure consistency in our argument. Further thanks are due to Ed Malecki and Andrew Munro.

\section{References}

Agrawal, A. and Henderson, R. (2002) Putting patents in context: Exploring knowledge transfer from MIT. Management Science, Vol. 48(1) pp.44-60.

Amin, A. and Thrift, N. (1995) Living in the global. In Amin, A. and Thrift, N., (eds.), Globalization, Institutions, and Regional Development in Europe, pp.1-22. Oxford University Press, Oxford, New York.

Aoyama, Y. (2009) Entrepreneurship and regional culture: The case of Hamamtsu and Kyoto, Japan. Regional Studies, Vol. 43(3), pp.495-512.

Arenius, P. and De Clercq, D. (2005) A network-based approach on opportunity recognition. Small Business Economics, Vol. 24(3), pp.249-265.

Association of University Technology Managers (2010) AUTM U.S. Licensing Survey: FY 2010. AUTM, Northbrook, IL.

Bathelt, H. and Hecht, A. (1990) Key technology industries in the Waterloo region: Canada's Technology Triangle (CTT). Canadian Geographer, Vol. 34(3), pp.225-234. 
Bathelt, H., Kogler, D., and Munro, A. (2010) A knowledge-based typology of university spinoffs in the context of regional economic development. Technovation, Vol. 30(9-10) pp.519-532.

Bathelt, H., Kogler, D., and Munro, A. (2011) Social foundations of regional innovation and the role of university spin-offs. Industry and Innovation, Vol. 18(5), forthcoming.

Benneworth, P. and Hospers, G.-J. (2007) The new economic geography of old industrial regions: Universities as global-local pipelines. Environment and Planning C, Vol. 25(5), pp.779802.

Bercovitz, J. and Feldman, M. (2008) Academic entrepreneurs: Organizational change at the individual level. Organization Science, Vol. 19(1), pp.69-89.

Bramwell, A., Nelles, J., and Wolfe, D.A. (2008) Knowledge, innovation and institutions: Global and local dimensions of the ICT cluster in Waterloo, Canada. Regional Studies, Vol. 42(1), pp.101-116.

Bramwell, A. and Wolfe, D.A. (2008) Universities and regional economic development: The entrepreneurial University of Waterloo. Research Policy, Vol. 37(8), pp.1175-1187.

Center for Entrepreneurship (2009) Cultivating the Future: 2009 Ohio Venture Capital Report. Ohio State University - Fisher College of Business, Columbus, $\mathrm{OH}$.

Cetindamar, D. and Lagge-Hellman, J. (2003) Growth dynamics in the biomedical/biotechnology system. Small Business Economics, Vol. 20(4) pp.287-303.

City of Toronto - Economic Development, Culture \& Tourism (2008) Toronto's Discovery District: Innovation, Technology, \& Business. City of Toronto - Economic Development, Culture \& Tourism, Toronto.

Colapinto, C. (2007) A way to foster innovation: A venture capital district from Silicon Valley and Route 128 to Waterloo Region. International Review of Economics, Vol. 54(3), pp.319-343.

Colyvas, J. (2007) From divergent meanings to common practices: The early institutionalization of technology transfer in the life sciences at Stanford University. Research Policy, Vol. $36(4)$, pp.456-476.

D'Este, P. and Patel, P. (2007) University-industry linkages in the UK: What are the factors underlying the variety of interactions with industry. Research Policy, Vol. 36(9), pp.1295-1313. 
Di Gregorio, D. and Shane, S. (2003) Why do some universities generate more start-ups than others? Research Policy, Vol. 32(2), pp.209-227.

Fini, R., Lacetera, N., and Shane, S. (2010) Inside or outside the IP system? Business creation in academia. Research Policy, Vol. 39(8), pp.1060-1069.

Griffith, T., Yam, P., and Subramaniam, S. (2007) Silicon Valley's 'one-hour' distance rule and managing return on location. Venture Capital, Vol. 9(2), pp.85-106.

Hannan, M.T. and Freeman, J. (1984) Structural inertia and organizational change. American Journal of Sociology, Vol. 49, pp.149-164.

Hayter, R. (1997) The Dynamics of Industrial Location: The Factory, the Firm and the Production System. Wiley, Chichester, New York.

Hsu, D., Roberts, E., and Eseley, C. (2007) Entrepreneurs from technology-based universities: Evidence from MIT. Research Policy, Vol. 36(5), pp.768-788.

Jensen, R., Thursby, J., and Thursby, M. (2003) Disclosure and licensing of university innovations: 'The best we can do with the $\mathrm{s}^{* *} \mathrm{t}$ we get to work with'. International Journal of Industrial Organization, Vol. 21(9), pp.1271-1300.

Julian, P. (2007) A Theory of Local Entrepreneurship in the Knowledge Economy. Edward Elgar, Cheltenham, UK.

Kenney, M. and Patton, D. (2005) Entrepreneurial geographies: Support networks in three hightechnology regions. Economic Geography, Vol. 81(2), pp.201-228.

Landry, R., Amara, N., and Rherrad, I. (2006) Why are some university researchers more likely to create spin-offs than others: Evidence from Canadian universities. Research Policy, Vol. 35(10), pp.1599-1615.

Langford, C.H., Hall, J., Josty, P., Matos, S., and Jacobson, A. (2006) Indicators and outcomes of Canadian university research: Proxies becoming goals. Research Policy, Vol. 35(10), pp.1586-1598.

Lockett, A., Wright, M., and Franklin, S. (2003) Technology transfer and universities' spin out strategies. Small Business Economics, Vol. 20(2), pp.185-203.

Lundvall, B.-Å. (1992) Introduction. In Lundvall, B.-Å., (eds.), National Systems of Innovation: Towards a Theory of Innovation and Interactive Learning, pp.1-17. Pinter, London.

Malecki, E.J. (1991) Technology and Economic Development: The Dynamics of Local, Regional, and National Change. Longman, Burnt Mill - Wiley, New York. 
Malecki, E.J. (1997) Entrepreneurs, networks, and economic development: A review of recent research. In Katz, J., (eds.), Advances in Entrepreneurship, Firm Emergence, and Growth, Vol. 3, pp.57-118. JAI Press, Greenwich, CT.

Malecki, E.J. (2009) Geographical environments for entrepreneurship. International Journal of Entrepreneurship and Small Business, Vol. 7(2), pp.175-190.

Markman, G.D., Gianiodis, P.T., Phan, P.H., and Balkin, D.B. (2005) Innovation speed: Transferring university technology to market. Research Policy, Vol. 34(1), pp.1058-1075.

Martinelli, A., Meyer, M., and von Tunzelmann, N. (2008) Becoming an entrepreneurial university? A case study of knowledge exchange relationships and faculty attitudes in a medium-sized, research-oriented university. Journal of Technology Transfer, Vol. 22(3), pp.259-283.

Mosey, S., Lockett, A., and Westhead, P. (2006) Creating network bridges for university technology transfer: The Medici Fellowship Programme. Technology Analysis and Strategic Management, Vol. 18(1), pp.1-91.

Mosey, S. and Wright, M. (2007) From human capital to social capital: A longitudinal study of technology-based academic entrepreneurs. Entrepreneurship Theory and Practice, Vol. 31(6), pp.909-935.

Murray, F. (2004) The role of academic inventors in entrepreneurial firms: Sharing the laboratory life. Research Policy, Vol. 33(4), pp.643-659.

Mustar, P., Renault, M., Colombo, M.G., Piva, E., Fontes, M., Lockett, A., Wright, M., Clarysse, B., and Moray, N. (2006) Conceptualising the heterogeneity of research-based spin-offs: A multi-dimensional taxonomy. Research Policy, Vol. 35(2), pp.289-308.

Niosi, J. (2000) Canada’s National System of Innovation. McGill-Queen's University Press, Montreal, Kingston.

Nonaka, I. and Takeuchi, H. (1995) The Knowledge Creating Company. Oxford University Press, Oxford.

Pirnay, F., Surlemont, B., and Nlemvo, F. (2003) Towards a typology of university spin-offs. Small Business Economics, Vol. 21(4), pp.355-369.

Powell, W., White, D.R., Koput, K.W., and Owen-Smith, J. (2005) Network dynamics and field evolution: The growth of interorganizational collaboration in the life sciences. American Journal of Sociology, Vol. 110(4) pp.1132-1205. 
PricewaterhouseCoopers (2001) Waterloo Region/Canada's Technology Triangle 2001:

Techmap. Consulting Report, PricewaterhouseCoopers, Waterloo.

Pries, F. and Guild, P. (2007) Commercial exploitation of new technologies arising from university research: Start-ups and markets for technology. R\&D Management, Vol. 37(4), pp.319-328.

Rothaermel, F. and Thursby, M. (2005) University-incubator firm knowledge flows: Assessing their impacts on incubator firm performance. Research Policy, Vol. 34(3), pp.305-320.

Samila, S. and Sorenson, O. (2010) Venture capital as a catalyst to commercialization. Research Policy, Vol. 39(3), pp.348-360.

Saxenian, A. (1994) Regional Advantage: Culture and Competition in Silicon Valley and Route 128. Harvard University Press, Cambridge, Mass.

Shane, S. (2004). Academic Entrepreneurship: University Spin-offs and Wealth Creation. Edward Elgar Publishing, Cheltenham, UK.

Shane, S. and Cable, D. (2002) Network ties, reputation, and the financing of new ventures. Management Science, Vol. 48(3), pp.364-381.

Sorenson, O. and Stuart, T. (2001) Syndication networks and the spatial distribution of venture capital investments. The American Journal of Sociology, Vol. 106(6), pp.1546-1588.

Spigel, B. (2008) The Geographies of Academic Knowledge Exchange. Unpublished Masters Thesis, The Ohio State University, Columbus, $\mathrm{OH}$.

The Ohio State University Office of Research (2009) 2009 Annual Report on Research. Columbus, $\mathrm{OH}$.

Vohora, A., Wright, M., and Lockett, A. (2004) Critical junctures in the growth in university high-tech spinout companies. Research Policy, Vol. 33(1), pp.147-175.

Wolfe, D. (2005) The role of universities in regional development and cluster formation. In Jones, G., McCarney, P., and Skolnik, M., (eds.), Creating Knowledge, Strengthening Nations: The Changing Role of Higher Education, pp.167-194. University of Toronto Press, Toronto.

Youtie, J. and Shapira, P. (2008) Building an innovation hub: A case study of the transformation of university roles in regional technological and economic development. Research Policy, Vol. 37(8), pp.1188-1204.

Zook, M. (2002) Grounded capital: Venture financing and the geography of the Internet industry, 1994-2000. Journal of Economic Geography, Vol. 2(2), pp.151-177. 
